Sergej Flere, Maribor

\title{
WHY DO POLITICAL ELITES FRACTURE? THE UNUSUAL CASE OF THE YUGOSLAV COMMUNIST ELITE
}

\section{Introduction}

One is on slippery grounds attempting to study closely societal elites in manner to coincide with the elementary meaning of the term. Classical thinkers, Pareto and Mosca, with daring analyses, remain cited today (see, for example, Dogan 2003; Burton - Higley 2001; Best - Higley 2010: 1), although the formers' constructs were hardly based on empirical findings, but were primarily the product of their "sociological imagination". Hence, the troubles confronted at analysing the elite are illustrated by Giddens (1974: 2): "there can exist a 'governing class' without necessarily being a 'ruling class'; there can exist a 'power elite' without necessarily being either a 'ruling' or a 'governing class"' and he continues to denote terms which do not coincide in depiction of power elites. As to the "doctrine", elites invoke, not only for the "ideocratic ones", but in general, Burton and Higley (2001: 186) hold a Paretian view: "Doctrinal unanimity is always more apparent than real." They also do not propose an operative definition of political elite's structure: "Political elites are somewhat elastic formations with unclear boundaries" (2001: 182). This complements the words of Mattei Dogan, another authoritative source on elites, who wrote: "Elite studies seem to be shut to a conceptual Tower of Babel, where scholars gamble with non-specified words" (Dogan 2003: 6).

On the other hand, there was great consent on the nature of political elites in European communist countries. For example, Djilas (1957), Aron (1968), and Burton and Higley (2001), held very similar views and contended the structure is simple, imposed by political violence, closed, ruling in the name of an ideology, the ideology being disconnected with social reality. For example, Djilas held simply that the "new class" [elite] operated via decision making and appropriation on the basis of state ownership. "The ownership privilege of the new class manifests itself as an exclusive right, as a party mo- 
nopoly, for the political bureaucracy to distribute the national income, to set wages, direct economic development, and dispose of nationalized and other property" (Djilas 1957: 44-45). Hence, the party elite would "own" the state.

Burton and Higley (2001: 188) develop the idea of Djilas's communist "new class" [elite] speaking of ideocracy: "An ideocratic elite is a stable unrepresentative regime in which power is monopolised by a single party or movement, so that power exercises and transfers jockeying for position within the uppermost body rather than dominating some representative body". Thus, Burton and Higley grant somewhat more elasticity in their comprehension of the communist ruling group than was put forward by Firedrich and Brzezinski (1956) in their famous piece at designating the "communist" and "totalitarian" dictatorship. The latter held it was a strictly hierarchical structure with a charismatic leader at the apex. With Burton and Higley, there is also no contention that the ideocratic elite would act in a perfect totalitarian rationality, making the state ever more totalitarian, but its operations are about "jockeying", i.e. manoeuvring and manipulating.

In this paper the evolution of the Yugoslav communist ruling elite will be focused: after ethnic disputes, it dissolved approximately in 1972. Some reasons for this unusual phenomenon are studied.

\section{The Yugoslav communist elite}

During World War II, Yugoslav communists, a relatively small group (a total of 1.200 members in 1941), organized a military movement, which took power at the end of the War. Their power changed from totalitarian to close to a perfect consociation, basically without external intervention.

The Yugoslav communist elite was subject of scholarly attention by Western social scientists. Significant assertions on the existence of a Yugoslav communist elite are to be found with Higley and Pakulski (1995: 416), Cotta (2018: 321) and others. For example, Higley, Hoffman-Lange, Moore and Kadushin (1991: 43) wrote explicitly in 1991 of a "Yugoslav national elite". Rusinow, in a well known monograph on Yugoslavia, published in 1978, also wrote of the Yugoslav political "elite" in the singular no less than 58 times (Rusinow 1978). Denitch (1990) wrote of a "Yugoslav political elite" as late as 1990, although he also had in mind elites in various other segments of social life and he would allow for republican variation of the political elite. In a study on Yugoslavia from 1972, the CIA also wrote of a "Yugoslav political elite" as hierarchically organised, without hesitation (Director of National Intelligence 1972: 5). As late as 2001, Burton and Higley erroneously hold that 
elite in Yugoslavia was "so centralized, one could speak of a single network" (Burton - Higley 2001: 185). Hence, there is an opulence of assertions on the existence of a single Yugoslav communist elite during the communist period (1945-1991). So, Western studies of the Yugoslav elite found it almost exclusively to be monolith in nature. Burg's 1986 study, when Yugoslavia itself was already, is the main example to the contrary.

These assertions were not without any foundation. Loosely, one can say that in the period of 1945-1991 in Yugoslavia initially there was a single elite, which did not encompass everyone who lived off of politics, but mainly the top communist party and government republic and federal functionaries. The elite was comprised of the ones who concentrated political power, although we would not limit it to the "apex" (possibly coinciding with the federal Party politburo) when describing it. In this paper we will be speaking of the political elite, knowing that other terms and concepts are also used, particularly nomenklatura, bureaucracy, estate, and upper class being the main ones. These terms involve differences in theoretical approaches, but mainly focusing on the same or similar aggregates (see, Eyal - Townsley 1995). It needs to be mentioned that no nomenklatura existed in Yugoslavia in the technical meaning of a list within which all key appointments were made. There were initiatives in this direction, particularly by Ranković in 1949, but such a single binding list was never established. There were lists both of key leaders in republics and provinces (for grandees to "rotate" among posts), particularly as of the 1970s, and there were partly successful attempts to draw lists of federal professionals from the republics and provinces to enforce republican-provincial control upon them (Burg 1983: 212-213; Flere - Klanjšek 2019: 264).

Prior to assuming power, i.e. before World War II Yugoslav communists had a volatile and ambivalent position on Yugoslavia. In all their statements they condemned the existing Yugoslav Kingdom as one of national oppression and Serbian Hegemony. In a few instances they upheld ideas on dissolving Yugoslavia into existing national groups and even national minorities and their territories. However, towards the end of the 1930s they began to uphold the idea of recreating a Yugoslavia as a federation, even previous to a communist revolution. This was particularly done by Tito in his well known "Letter for Serbia" (Tito 1982: 3, 37) addressed to Veselin Masleša.

However, this was short of considering Yugoslavia as desirable and Djilas notes that at the beginning of the War "Yugoslavia was not regarded as a value" (Đorgović in Đilas 1989).

So, Yugoslavia, although contested, was transformed into a "value" during the uprising the communist leaders undertook. But it was considered so con- 
ditionally, as a home where the nationhoods would be at par, fully equal. This was never forgotten to be mentioned by communists, although some may have considered it as lip service, only formal acquiescence. However, particularly non-Serb communists held it to be essential. Throughout the 1941-1991 period it never ceased to be mentioned by communists.

However, something more would be needed for Yugoslavia to be a "happy" land, as Tito titled it at numerous occasions in 1945, for example at the Congress of the Serbian CP in May 1945 (Osnivackki kongres 1972: 210) and at speech in Zagreb to citizenry in the same period. To this end, something else would be needed, not just national parity.

Beside a socially just order, which would eradicate exploitation, and national parity, which would govern interethnic and inter-regional relations, a very important initial goal of Yugoslav communists was a developmentalist one. They believed by the new "scientific" management of the economy, it would speedily become a rich one. On of the major goals of the Yugoslav communist elite at the inception of its power, for example, in 1945, was to develop Yugoslavia economically at a speedy pace. This resonated in the speeches of Tito, Djilas and Kidrič, particularly. For example, in a 1946 speech Djilas (1948: 268) held “...that in fifteen, twenty years' time (foreign enemies, i.e. the western states)" ... "will be caught up with and overtaken in all matters". "This is not to be doubted even slightly for it will be so...".

The Yugoslav communist elite underwent segmentation well before the dissolution of Yugoslavia itself. The process took place between 1962 and 1972.

\section{Elite's operational difficulties and segmentation}

The phenomenon of the fracturing is intriguing, including the comparison to the Soviet dissolution, where also there was a communist multi-national elite. In the Soviet case, the elite's dissolution did not precede the dissolution of the Soviet Union where there was a multi-national unity of "coercive state institutions, conservative party structures, and the military-industrial complex" as late as "August 1991" (Vujačić 1996: 763), in opposition to a variety of anti-communist "parade of sovereignties". In the third case of dissolution of a communist federation, Czechoslovakia, the fall of communism preceded the dissolution by more than two years, so that there was no communist elite on the stage to intervene (Musil 1995; Bunce 1999: 96-98). So, a comparative approach would be of no help in the Yugoslav instance of elite segmentation. One is confronted by a unique case. We need to turn attention to the specifics 
of internal processes. It is needed to analyse again the goals of the Yugoslav communist elite enabling their joining into a single group with unconditional resolve and unconditional acceptance of a leader. As is known, this was initially a very small group, of probably less than one hundred revolutionary, although certainly not limited to the Politburo members in the War period.

Stumbling blocks on the road of development made their presence soon and they would prove unsurmountable. They would also be the subject of elite conflicts.

The early issues had to particularly with difficulties of agricultural production in the immediate post-war situation. Compulsory delivery (of agricultural produce) was legally mandated in 1946 (after sequestration of produce in favour of the armed forces was abandoned), and it was combined with heavy, "progressive" taxation of peasants. Police enforcement and a propaganda campaign were included (there were instances peasants were literally beaten at enforcement, Petranović - Končar - Radović 1985: 558). "The issue cannot be viewed from the point of a former jurist, for whom this would be terrible and horrible", Đilas would state, but we need to "search for the causes" (Petranović - Končar - Radović 1985: 558). The market surplus peasants were forced to deliver truly hardly existed, and peasants were not motivated to produce it. They received no help from the state in the form mechanization or fertilizer.

This unrealistic policy and its imminent failure was reflected in inter-ethnic relations among top communists, who began to point fingers at each other. Nešković, head of the Party in Serbia, was, with respect to compulsory delivery, in 1947, unjustly pressed to suck out by force more than was produced in 1947 by the Vojvodinian peasants (Politburo session on March 4, 1947). Nešković opposed delivery quotas. Kidrič, Kardelj, Tito and others criticized him strongly for not accepting the quota plan, for distancing himself from the 5 economic year plan in general. He was labelled "opportunist", "practicist" and "un-self-critical", for being "disrespectful to such an experienced and long-standing communist as Kidrič" (Archives of Yugoslavia, CK SKJ, III/24, Petranović - Zečević 1987, II: 313-318). Same criticisms and clashes also came about at the Federal Economic Council in 1947-1949, among the same participants and along the same lines (Zečević - Lekić 1995).

Kidrič seemed to be the most "idealist" in enforcing the 5 year plan, as testified by Velebit much later (2016). One can trace of the Slovene origin of pressure for Vojvodina wheat, where Nešković defended peasants who were not able, under conditions given, to deliver as much as was requested. At the end of the meeting, Tito concluded to diminish the quotas. He also concluded 
that Nešković's behavior did not add up to "chauvinism" (this last condemnation will be rendered later, in 1952, bringing about his fall).

Later on, conflicts often had to do with the distribution of foreign loans among republics. We will focus on one event only in the 1969-1972 period: "the Slovene highway affair".

The so called "highway affair" (1969) also resonated in the Yugoslav public. It came about due to the Slovene leaders endeavouring to draw a disproportional part of funds from the International Bank for Reconstruction and Development for the construction of highways, although the loan was intended for the development of underdeveloped regions. In particular, Slovenia was already granted a loan for highways in Upper Carniola (in the previous round). The federal government, headed by Slovene Mitja Ribičič, denied access to funds for highway sections Hoče-Levec and Postojna-Razdrto. This decision on July 31, 1969 was resisted by the Slovene government, led by Stane Kavčič. It was strongly supported by the Slovene public, which was informed of the issue. The Slovene government demanded that the federal government reconsider its decisions and threatened with opening discussion on issue in the Slovene parliament. There were public protests, as the public was informed that the highway construction was a Slovene economic necessity. Slovene leaders also considered it in the general interest, a most profitable investment. This opinion was upheld as Belgrade economic weekly Ekonomska politika opined ("Dimenzije autoputa", August 4, 1969), which commented it was unimportant than each part of Yugoslavia have a petite portion of highway at "120 kilometres per hour". However, entity parity was the mode of operation. Throughout Yugoslavia there was dissatisfaction with Slovene claims. As a consequence, dissatisfaction with Yugoslavia was demonstrated in Slovenia - the head the Party Committee of Celje, reported on "requests for independent Slovenia" (Repe 1992: 784).

Reactions in other parts of Yugoslavia were to the contrary. For example, in Bosnia and Herzegovina an opinion was as to the situation in Slovenia the situation being "beyond control" (Repe 1992: 771), whereas Serb leader Milentije Popović commented we "don't need federal authorities at all, if one enters negotiations with plebiscitary support by one's respective republic" (Repe 1992: 771). The federal government was titled, concluded in August 1969 , probably according to Tito's wishes, that "possibilities have been created for the class enemy to enter into the political arena" (Repe 1992: 768). It was also alleged that Mitja Ribičič, as federal Prime Minister, a Slovene, complained to Tito that a campaign was launched by Kavčič against him, the campaign being of "mass proportions" and that it was also directed against 
the federal government (see, for example, Bilandžić 2006: 80). This was true. The Slovene Executive Council had in fact rejected rules of the the Yugoslav state, rules on parity. Instead, Kavčič pleaded for purported economic justification of investment as criterion. Subsequently, the Sixteenth Meeting of the Party Politburo was convened in August 1969, where the leadership, headed by Tito, designated the "highway affair" as example of nationalism and Tito accused Kavčič of attacking the unity of the federal state. This was followed by division inside the Slovene leadership ending in "purge" in Slovene leadership. Tito probably felt, at the late age, needing to establish some order, suppressing nationalist particularism.

A third moment at fracturing the Yugoslav elite may be illustrated by the norm of absolute "national interest" observance could also be discerned in the so-called Slovene highway affair. There were other instances of the application of this rule, regarding foreign loans and their repayment, subsidies, foreign currency rate and access, but possibly the most toxic was the issue of Kosovo status, the claim for republic status by Albanian leaders and the denial by Serbian leaders. These issues addressed by politicians were supplemented by no less toxic contributions by the political elite on non-negotiable identity issues, like language, history interpretation etc. "Softness" regarding the interests of other nationhoods would also not be tolerated, as the cases of oustings at the republican level of Dobrivoje Radosavljević and Miloš Žanko illustrate (Flere - Klanjšek 2019: 95-96).

This manner of operation may be considered typical. Members of the elite, of the elites to be more precise, were led exclusively by their perception of the national interest and were not prepared to make concessions or compromises. Nor was there a "Yugoslav interest" in their perception.

National, republic interest made up the system of thought and system of operation. It was a deviation of the original 1945 developmentalist position. Confronted by failure to achieve it they deviated into its implementation at the republic level, which also fit into the ideological credo, as national parity was also founding pillar of the ideology and of the system. The system operated in manner defined by Pareto: In Trattato, Pareto writes that elite members "are carried along by the sheer force of the system to which they belong, involuntarily, and indeed against their will, following the course that is required by the system" (para. 2254, quoted by Pakulski 2018: 23). Andrej Marinc would comment on decision making motives in 2018: "We always advanced progressive solutions, as to Slovenia and as to Yugoslavia" (interview). He perceived no contradictions between the two. 
The cracking of the communist elite under the weight of these difficulties was demonstrated already in 1962. The March 1962 Politburo session could not be ended by any decisions, due to Slovene-Serb variance as to how to develop the Yugoslav system and signs of others perceiving their interests in the situation. The 1962 crack was led by Slovene and Serbs leaders, the former demanding more autonomy, the latter demanding a more struct unity, which will remain both the two leading nationalisms and their narratives. Macedonians were also articulate in 1962, whereas Croats would usually be tacit, except in the 1969-1971 period, when they were most articulate on the scene (Flere - Klanjšek 2019: 110-111).

Communist leaders were basically permeated by collective goals, initially Yugoslav ones, later national ones. Communist coloured goals, but even more developmentalist ones. These developmentalist ones would finally, during the 1980s be transferred into notions of autarkic economies.

The process of elite fragmentation continued until approximately 1972 when republican (and provincial) elites, national ones became constituted. This was demonstrated by their controlling of the "republican" officials, including non-political professionals in the federal offices and most particularly by the constitutional arrangement adopted then (in the 1971 Constitutional amendments and in the 1974 Constitution, Flere - Klanjšek 2019: 115-125).

Only a few examples of the process of segmentation are given, for brevity's sake (see, Flere - Rutar 2019, for greater detail).

\section{Forces driving the fracturing}

It has been established that the Yugoslav communist elite, initially a singled, united, ideocratic one, fractured along republican and national ones (for more details, see Flere - Rutar 2019). Western sociologists, with rare exceptions, did not notice this process.

But which forces brought this segmentation about? We noted some of the phenomenology of the elite's operation and its difficulty, leading towards republican segments to close down.

\section{The political system}

The first issue needing consideration is the manner of operation of the political system. Already Bunce noticed that the federal multi-ethnic communist systems operated in favour of the constituents and against the centre, although it seemed the opposite. But the Yugoslav case was the most drastic. She had institutions in mind, not elites, however (2001). 
As of 1971, it was a full constitutional consociation, except for the manner of elections which was a complicated indirect one without competitive groups. But as to operation, including the formal rules of operation (constitutional provisions, business rules), it was as if Lijphart had himself laid the rules down. To be more precise, it was the predetermined, corporate type of consociation, where political agents, in this case republics and provinces had (equal, surpassing Lijphart's demands for proportional) representation in the federal government provided, as well as in all other federal bodies, where they disposed with veto power and where in federal decision making and each republic and province availed itself the power of cultural autonomy (Lijphart et al. 1991). Ethnic groups were entrenched in the power sharing. It surpassed the 6:4 legislative representation of Flemish and Walloons in Belgium (Billiet - Frognier, 2006). Irrespective of electoral results. In Yugoslavia there was equal representation of republics in both parliamentary houses and somewhat lesser of the provinces.

The 1974 formula, in particular, gave grounds to the republic elites to hold to their veto until their economic requests were not met in full (in spite of popular speech on austerity). Republican investments continued and the adoption the federal budget during the 1980s was never in an ordinary manner, by the parliament adopting the government's proposal. Always, republican elites in the parliament demanded republics being relieved of financing the federal government (Flere - Klanjšek 2019: 137-144).

However, these ruling elites, continuing to run the country upon Tito's passing away, although growing more aggressive and desperate, never themselves took steps to break away from Yugoslavia. By 1986 the Slovenian and the Serbian elite became aware that support for non-communists was needed to strengthen the republic position.

Hence, we can speak with fair certainty that consociation, in the Yugoslav case, of constituted nations are at issue, strengthened identities and entrenched regional/republican positions, making compromises next to impossible. One can discern that the consociational arrangement operated strengthening republic and province lies themselves as entities, their independence and selfawareness as bearers of national interest, entrusted with the further assertion of national interest and the definite "resolution of their [respective] national question". However, we cannot hold this was decisive nor can we hold the elites were not well on their way to constitution, as was discernible in 1962.

The effects were fully in line with what critics of predetermined consociationism point to: "Consociationalism is likely to freeze existing divisions and to result in political immobilism" (Jarstad 2009: 502). "Power sharing institu- 
tions empower ethnic elites ... create incentives for these elites to press radical demands ... lower the costs for these elites to escalate conflict in ways that threaten democracy and peace." (Rothschild - Roeder 2005: 29). In short, newer political science proposals disfavour this "predetermined" consociation type in favour of one determined by each electoral results.

Therefore, criticism of the Lijpahrtian formula, particularly of this version of the formula where operation of the consociation is independent of electoral results, is very pertinent in the Yugoslav case, although the political scientists did not have Yugoslavia in mind.

However, this cannot be held the entire explanation, particularly in view that the constitutional arrangement was produced by the political elites themselves, so that this may be viewed as a circulatory explanation.

\section{The nature of political elites}

Elite theory is conspicuously silent on how the political elite operates in multi-national, multi-ethnic political states. Best and Higley's voluminous Palgrave Handbook of Political Elites (Best - Higley 2018) contains no chapter on such situations, although they evidently do exist or could potentially be defined as such. In Europe, Belgium and Switzerland are certainly such cases. When Switzerland is mentioned, there is no reference to its multinational nature, it is treated as a mono-national entity, although cantons are mentioned (Best - Higley 2018: 33). In the other volume edited by the same authors (2010), there is a chapter which by its title could focus on the problem we are interested in. However, Steen and Kuklys (Best - Higley 2010: 197-213) present the cases of the three Baltic states during post-communist transition as "multi-ethnic" ones, underlining the need to integrate Russians minorities into political decision making processes, which is truly not the issue we are interested in. These three nations are basically mono-national ones, and "nationalizing" at that, as Brubaker notes it. Mattei Dogan in his 2003 volume also made reference to "multinational" only in the context of corporations. This is basically the state of contemporary theory, somewhat at variance with Putnam's earlier work, who did have a sense for multi-ethnicity (Putnam 1976: 115-121), who cursorily related "multi-ethnicity of elites to their fragmented nature", an issue which will later be considered by Higley and Best as a sign of their underdevelopment on the imminent path to their consensual nature, accepting the existence of political opponents and not attempting to annihilate them, but just to take turns in operating the political 
regime. Thus, toleration of the opposition and making conditions for opposition operation is the major achievement in political modernization.

Hence, Higley and Best and the entire theory of "democratic elitism" focus on political power holders - opposition relationship, which needs to be a tolerant one, this being the most important condition for the operation of modern political systems, which they do not consider truly democratic, democracy being not possible to achieve. "The vital step is the consensual unification of previously disunified elites" (Higley - Pakulski 2012: 294).

Orderly change of power holders and their taking of opposition roles is vital, however. They could be aware of ethnicity in this context, but they do not consider it as relevant. As noted, they always write or bear in mind "national elites", which may be understood as state political elites or mono-ethnic state elites, not considering the issue worthy of elaboration.

However, what we are interested in, the multi-national (multi-ethnic) elite which is simply not dealt with by the democratic elite school. This is not a coincidence nor a slip. It is the position that political and ruling elite can be constituted almost exclusively on a mono-national basis. There are many instances in the works by Best, Higley, Pakulski, and Burton where this tacit but certain position is evidenced. In fact, they all hold it as so evident they do not feel the need to corroborate it.

For example, Burton and Higley write in 2001: "Each elite subtype has a foundational origin in the formation of national states. Forming a national state ... typically involves a forcible repression and subjugation of some elite groups by others who end up dominating the new state ... This was the case of all European national states..." (Burton - Higley 2001: 186).

In 2003, Mattei Dogan wrote: "Given the diversity of national elite configurations, an appropriate strategy for scrutinizing them is the comparison of pair of countries..." (Dogan 2003: 6).

This complements the position of Gellner and of other modernists on what a nation and a nation-state are. Functionally, a culturally homogenous population is needed, whatever the demographic basis may be.

We may thus gather that in Yugoslavia there was a basic determinism of the elite's segmentation along ethnic and republican lines due to the very nature of the nation and the political elite. Nations in the communist Yugoslav setting themselves developed and matured. They evolved from different points in the evolution of nations. One may hold some of them were "mature" in 1945, whereas other were not, which is beyond the scope of this paper.

The Yugoslav communist elite in 1945 was thrilled by the immense victory, enthused by the vistas of economic development and political power. 
At that moment they somewhat departed from reality. However, one can say members of the elite "sobered" by the difficulties they encountered. These were both political and economic in nature. The initial danger they found themselves in (the Cominform split with Stalin) produced a homogeneity and unity, but with that peril withering away the basic nature of political elites would come into the forefront: they were agents of their nationhoods.

One can ask why the Yugoslav communist elite did not choose the path suggested by Burton, Higley and Pakulski? The path of consensual tolerance. Or was such a path open to them? For brevity's sake, the short answer is in the fact that the elite was originally opposed to liberalism of any kind and on the other hand, such a path would lead to inter-ethnic conflict and dissolution, as it did in 1991. The communist leaders believed that communist ideology does contain itself a harmonization needed in the multi-ethnic circumstances.

\section{Conclusion and discussion}

What kind of relevance does what has been noted above have on explaining the Yugoslav communist political elite fracturing?

With some hesitation, one is tempted to hold that by an indirect, devious way the Yugoslav elite led to normality. From a uniform multi-ethnic, but highly ideological and intolerant elite, it slowly passed into the "natural" mould of national elites.

Whether natural or not, which may be questionable, another issue is even more relevant: did elite action pave the way for changes in the political system, opening the way to dissolution of the Yugoslav state, or was it vide versa, did political, institutional changes pave the way for elite segmentation. This is an issue which cannot be answered in a single position: the processes were intermingled, as the elite and the institutional system overlapped. They were led by their ideological tenets, including "solving the national question", i.e. catering for their nationhood, leading them to ever more loose arrangements, giving each national elite greater agency and subjectivity. As Kardelj would immodestly tell Slovene leaders in 1973, coming from Brioni final negotiations on the 1974 constitution, finalizing the consociational arrangement: "This was the best I can do to save Yugoslavia" (testimony of Andrej Marinc to author, 2018).

One cannot hold nationhoods are objective, self-explanatory. They are constructs, in the process of formation they can be moulded. But in the time of Tito's Yugoslavia, nationhoods, although not all were mature, were beyond the point of return to a no-nationhood. 
We have noted a major lacuna in contemporary elite theory: to deal directly with multi-ethnic elites in multi-ethnic states. Like Belgium (Billiet Frognier 2006), for example, where there are notable fractures having a major bearing on politics. Although the issue has been dealt with, it has not been integrated into contemporary elite theory. Like the Yugoslav case, which was dealt with in some instances outright erroneously.

The constitution of national political elites certainly involved also cultural elites. In contrast to the political elite, which was initially a single one, there were national cultural elites from the beginning and they also contributed to the constitution of national political elites by asserting some non-negotiable identity issues (see, Flere - Klanjšek 2019: 76-82, 89, 155-158).

Rational choice was not applied as a possible explanatory variable, as it is evidently inappropriate for such complex issues (Malešević 2004).

\section{References}

Aron, Raymond (1968), Democracy and Totalitarianism, Widefeld and Nicolson, London.

Best, Heinrich - Higley, John (eds.) (2010), Democratic Elitism: New Theoretical and Comparative Perspectives, Brill, Leiden.

Best, Heinrich - Higley, John (2010), Introduction: Democratic elitism reappraised. In: Heirich Best - John Higley (eds.) Democratic Elitism: New Theoretical and Comparative Perspectives, Brill, Leiden, pp. 1-22.

Best, Heinrich - Higley, John (eds.) (2018), The Palgrave Handbook of Political Elites, Palgrave, London.

Bilandžić, Dušan (2006), Povijest izbliza - memoarski zapisi 1945-2005, Prometej, Zagreb. Billiet, Jaak - Frognier, Andre-Paul (2006), Does Belgium (still) exist? Differences in political culture between Flemings and Walloons, West European Politics, Vol. 29, No. 5, pp. 912-932.

Bunce, Valerie (2001), Subversive Institutions: The Design and the Destruction of Socialism and the State, Cambridge University Press, Cambridge.

Burg, Steven L. (1983/1984), Conflict and Cohesion in Socialist Yugoslavia. Political Decision Making since 1966, Princeton University Press, Princeton, NJ.

Burg, Steven L. (1986), Elite conflict in post-Tito Yugoslavia, Soviet Studies, Vol. 38, No. 2, pp. 170-193.

Burton, Michael - Higley, John (2001), The study of political elite transformations, International Review of Sociology, Vol. 11, No. 2, pp. 181-199.

Cotta, Maurizio (2018), Elite Dilemmas and Dynamics. In: H. Best - J. Higley (eds.) The Palgrave Handbook of Political Elites, Palgrave, London, pp. 563-573.

Denitch, Bogdan (1990), Limits and Possibilities. Crisis of Yugoslav Socialism and State Socialist Systems, University of Minnesota Press, Minneapolis, MN.

Djilas, Milovan (1948), Članki: 1941-1946, Cankarjeva založba, Ljubljana.

Djilas, Milovan (1957), The New class. An Analysis of the Communist System, Thames and Hudson, London.

Dogan, Mattei (2003), Introduction: Elite configurations and clusters of power. In: Mattei Dogan (ed.) Elite Configurations at the Apex of Power, Brill, Leiden, pp. 1-17. 
Doprinos akademika Ivana Cvitkovića razvoju sociologije religije (Povodom 75. godišnjice života)

Eyal, Gil - Townsley, Eleanor (1995), The Social Composition of the Communist Nomenklatura: A Comparison of Russia, Poland and Hungary, Theory and Society, Vol. 24, No. 5, pp. 723-750.

Flere, Sergej - Klanjšek, Rudi (2019), The Rise and Fall of Socialist Yugoslavia: Elite Nationalism and the Collapse of a Federation, Rowman and Littlefield, Lanham, MD.

Flere, Sergej - Rutar, Tibor (2019), The segmentation of the Yugoslav communist elite, Družboslovne razprave (in print).

Friedrich, Carl J. - Brzezinski, Zbigniew (1956), Totalitarian Dictatorship and Autocracy, Harvard University Press, Cambridge.

Giddens, Anthony (1974), Elites in the British class structure. In: P. Stantoworth - A. Giddens (eds.) Elites and Power in British Society, Cambridge University Press, Cambridge.

Higley, John - Pakulski, Jan (2012), Elite foundations of social theory of politics, Historical Social Science Research, Vol. 37, No. 1, pp. 292-319.

Higley, John - Hoffman-Lange, Ursula - Kadushin, Charles - Moore, Gwen (1991), Elite integration within stable democracies: A reconsideration, European Sociological Review, Vol. 7, No. 1, pp. 35-53.

Horowitz, Donald L. (2001), Ethnic Groups in Conflict, 2nd ed, University of California Press, Berkeley.

Jarstad, Anna (2009), The Prevalence of Power-Sharing: Exploring the Patterns of PostElection Peace, Africa Spectrum, Vol. 44, No. 3, pp. 41-62.

Lijphart, Arend - Crepaz, Markus M. L. (1991), Corporatism and Consensus Democracy in Eighteen Countries: Conceptual and Empirical Linkages, British Journal of Political Science, Vol. 21, No. 2, pp. 235-246.

Malešević, Siniša (2004), Sociology of Ethnicity, SAGE, Thousand Oaks, CA.

Musil, Jiri (1995), The End of Czechoslovakia, Central University Press, Budapest.

Osnivački kongres KP Srbije 1945. (1972), Institut za istoriju radničkog pokreta, Beograd.

Pakulski, Jan (2018), Classical elite theory: Pareto and Weber. In: Heinrich Best - John Higley (eds.) The Palgrave Handbook of Political Elites, Palgrave, London, pp. 17-24.

Petranović, Branko - Končar, Ranko - Radonjić, Radovan (eds.) (1985), Sednice Centralnog komiteta KPJ: 1948-1952. Komunist, Beograd.

Putnam, Robert C. (1976), Comparative Study of Political Elites, Prentice Hall, Englewood Cliffs, NJ.

Repe, Božo (1992), Liberalizem v Sloveniji, Borec, Ljubljana.

Rothschild, Donald - Roeder, Philip G. (2005), Dilemmas of State-Building in Divided Societies. In: Philip G. Roeder - Donald Rothchild (eds.) Sustainable Peace: Power and Democracy after Civil Wars, Cornell University Press, Ithaca, NY, pp. 1-26.

Rusinow, Dennison (1978), The Yugoslav Experiment, 1948-1974, C. Hurst, London.

Tito, Josip Broz (1982), Sabrana djela, Volume III, Komunist, Beograd.

Velebit, Vladimir (2016), Moj život, Fraktura, Zagreb.

Vujačić, Veljko (1996), Historical legacies, nationalist mobilization, and political outcomes in Russia and Serbia: A Weberian view, Theory and Society, No. 25, pp. 763-801.

Zečević, Miodrag - Lekić, Bogdan (eds.) (1995), Privredna politika vlade FNRJ, Zapisnici Privrednog saveta Vlade FNRJ 1944-1953, Volume 1, Arhiv Jugoslavije, Beograd. 